\title{
UPAYA KEPALA MADRASAH DALAM MENINGKATKAN KOMPETENSI PROFESIONAL GURU
}

\author{
Nurul Akhyar \\ Universitas Islam Negeri Maulana Malik Ibrahim Malang \\ e-mail: akhyarphobia@gmail.com
}

\begin{abstract}
Teacher competency enhancement must be carried out by the head of the madrasah continuously so that teacher competency always increases and the teacher becomes a great and qualified teacher. The objectives of this study include; 1) Describe the headmaster's efforts in improving the competence of Madrasah Ibtidaiyah Al-Maarif02 Singosari teachers. 2) Description of the supporting and inhibiting factors that affect the head of the madrasah in enhancing the competence of teachers of the Madrasah Ibtidaiyah Al-Maarif 02 Singosari. To achieve the above objectives, the researcher used a qualitative approach with a type of descriptive research. The location of this study was conducted at MI Al-Maarif 02 Singosari Malang. The informants in this study were the head of the madrasa and the class teacher. The technique of collecting data uses interviews and documentation. To analyze the author's data using qualitative descriptive analysis. The findings of this study are: 1) the head of the madrasa conducts an effort that is formally done namely by Rutinan Meetings, includes training, teacher training and seminars, inter-teacher / KKG group studies, supervision and class visits and Conducting Assessments, while non-formal activities are by familiarizing discipline and always providing motivation with the aim of increasing the teacher's insight, providing opportunities for teachers to improve the spirit of discipline and teacher skills,2) Supporting factors affecting the madrasah head in increasing teacher competency are the fulfillment of madrasah infrastructure that is fulfilled, enthusiastic and enthusiastic about the teachers participating in the training, and the support of the foundation while the inhibiting factors faced by the madrasa principals are; the head of the madrasa itself and the teacher who is not in the madrasa.
\end{abstract}

Keywords. Efforts of Madrasah Heads, Teacher Competencies

Abstrak. Peningkatan kompetensi guru harus dilakukan oleh kepala madrasah secara terus-menerus sehingga kompetensi guru selalu mengalami peningkatan dan guru menjadi guru yang hebat dan berkualitas. Adapun tujuan dari penelitian ini antara lain; 1) Mendeskripsikan upaya kepala madrasah dalam meningkatkan kompetensi guru madrasah ibtidaiyah Al-Maarif 02 Singosari. 2) Mediskripsikan faktor pendukung dan penghambat yang mempengaruhi kepala madrasah dalam meningkatkan kompetensi guru madrasah ibtidaiyah Al-Maarif 02 Singosari. Untuk tercapainya tujuan diatas maka peneliti menggunakan pendekatan kualitatif dengan jenis penelitian deskripsi. Lokasi penelitian ini dilakukan di MI Al-Maarif 02 Singosari Malang. Informan dalam penelitian ini adalah kepala madrasah dan guru kelas. Teknik pengumpulan data menggunakan wawancara dan dokumentasi. Untuk menganalisis data penulis menggunakan analisis deskriptif kualitatif. Temukan penelitian ini adalah: 1) Kepala madrasah mengadakan upaya yang dilakukan secara formal yaitu dengan Rapat Rutinan, mengikutkan pelatihan, diklat dan seminar guru, studi kelompok antar Guru / KKG, Supervisi dan kunjungan kelas dan Mengadakan Penilaian, sedangkan kegiatan yang dilakukan non formal yaitu dengan membiasakan kedisiplinan dan selalu memberikan motivasi dengan tujuan untuk menambah wawasan guru, memberikan kesempatan kepada guru-guru untuk meningkatkan semangat disiplin dan keterampilan guru. 2) Faktor pendukung 
yang mempengaruhi kepala madrasah dalam meningkatkan kompetensi guru adalah terpenuhinya sarana prasarana madrasah yang terpenuhi, antusias dan semangat para guru turut serta dalam pelatihan, serta adanya dukungan dari yayasan. Sedangkan faktor penghambat yang dihadapi kepala madrasah, adalah; diri kepala madrasah sendiri dan adanya guru yang tidak tepat masuk madrasah.

Kata Kunci. Upaya Kepala Madrasah, Kompetensi Guru

Copyright (C) JMPI: Jurnal Manajemen Pendidikan Islam. All Right Reserved.

This is an open access article under the CC BY-NC-ND license

(http://creativecommons.org/licenses/by-nc-nd/4.0/).

\section{A. PENDAHULUAN}

Pendidikan merupakan pilar utama dalam konteks pengembangunan bangsa dan negara. Hal ini dapat terlihat dari tujuan nasional bangsa Indonesia yaitu mencerdaskan kehidupan bangsa, yang menem pati posisi strategis dalam pembukaan UUD 1945. Dalam pendidikan formal di sekolah, guru merupakan komponen yang penting dalam meningkatkan dan mengembangkan mutu pendidikan. Dengan demikian, guru merupakan komponen yang paling berpengaruh terhadap terciptanya proses dan hasil pendidikan yang berkualitas.

Pemerintah telah merancang dan menetapkan standar kompetensi, kualifikasi dan sertifikasi guru sebagai usaha untuk menghasilkan guru yang profesional, yang memiliki kompetensi untuk melaksanakan fungsi dan tujuan sekolah khususnya, serta tujuan pendidikan pada umumnya. Dapat diidentifikasi beberapa karakteristik guru yang dinilai kompeten secara profesional. Sebagai berikut: (1) mampu mengembangkan tanggung jawab dengan baik, (2) mampu melaksanakan peran dan fungsinya dengan tepat, (3) mampu bekerja untuk mewujudkan tujuan pendidikan di sekolah, (4) mampu melaksanakan peran dan fungsinya dalam pembelajaran di kelas (Hamalik, 2010).

Kepala Sekolah sebagai pemimpin dalam pendidikan formal perlu memiliki wawasan kedepan. Kepemimpinan pendidikan memerlukan perhatian yang utama, karena melalui kepemimpinan yang baik kita harapkan akan lahir tenaga-tenaga berkualitas dalam berbagai bidang sebagai pemikir, pekerja yang pada akhirnya dapat meningkatkan sumber daya manusia yang berkualitas. Hal yang terpenting bahwa melalui pendidikan kita menyiapkan tenaga-tenaga yang terampil, berkualitas dan tenaga yang siap dipakai untuk memenuhi kebutuhan masyarakat bisnis dan industri serta masyarakat lainnya (Atmadiwiryo, 2000).

Sosok pemimpin dalam hal ini seorang kepala sekolah selaku penanggung jawab pengelolaan administrasi dan teknis pembelajaran diharapkan mampu bertindak selaku manager dalam upaya menumbuh kembangkan kompetensi guru lewat pemberdayaan kompetensi guru melalui bentuk penghargaan seperti pemberian kesempatan sertifikasi guru, pendidikan dan latihan profesi, penyediaan sarana pendukung pembelajaran, pemerataan jam pembelajaran, pemberian insentif berdasarkan tugas dan tanggung jawabnya serta pemenuhan jaminan kenyamanan dan keamanan dalam menjalankan tugas pembelajarannya.

Pada dasarnya kepala sekolah melakukan tiga fungsi sebagai berikut yaitu: membantu para guru memahami, memilih, dan merumuskan tujuan pendidikan yang akan dicapai, menggerakkan para guru, para karyawan, para siswa, dan anggota masyarakat untuk mensukseskan program-program pendidikan di sekolah, 
menciptakan sekolah sebagai lingkungan kerja yang harmonis, sehat dinamis, nyaman sehingga segenap anggota dapat bekerja dengan penuh produktivitas dan memperoleh kepuasan kerja yang tinggi (Kusmintaro dan Burhanuddin, 1997).

Salah satu faktor utama yang menentukan mutu pendidikan adalah guru. Gurulah yang berada di garda terdepan dalam menciptakan kualitas sumber daya manusia. Guru berhadapan langsung dengan para peserta didik di kelas melalui proses belajar mengajar. Di tangan gurulah akan dihasilkan peserta didik yang berkualitas, baik secara akademis, skill (keahlian), kematangan emosional dan moral serta spiritual. Dengan demikian, akan dihasilkan generasi masa depan yang siap hidup dengan tantangan zamannya. Oleh karena itu, diperlukan sosok guru yang mempunyai kualifikasi, kompetensi dan dedikasi yang tinggi dalam menjalankan tugas profesionalnya (Kunandar, 2008).

Kebanyakan guru belum memiliki kompetensi yang memadai untuk menjalankan tugasnya sebagaimana disebut dalam pasal 39 UU No 20/200, yaitu merencanakan pembelajaran, melaksanakan pembelajaran, menilai hasil pembelajaran, melakukan pembimbingan, melakukan pelatihan, melakukan penelitian, dan melakukan pengabdian masyarakat. Sebagian guru di Indonesia bahkan dinyatakan tidak layak mengajar (Jamal Ma' mur asmani, 2009).

Kondisi guru di atas sangat memprihatinkan. maka, tidak ada jalan lain kecuali memacu semangat belajar guru untuk terus meningkatkan kompetensinya, melalui kuliah, banyak membaca, menulis, berdiskusi, berorganisasi, dan mengembangkan jaringan ke luar. Salah satunya dengan cara mengikut sertakan program pendidikan dan pelatihan serta kegiatan lainnya. karena jika tidak, semua upaya tersebut tidak akan membawa hasil tanpa ada niat yang kuat dari guru tersebut. Sebab, tanggungjawab dalam mengembangkan kualitas dan kompetensi pada dasarnya merupakan tuntutan kebutuhan pribadi guru itu sendiri, tanggungjawab meningkatkan dan mengembangkan kompetensi tidak dapat dilakukan oleh orang lain kecuali oleh guru itu sendiri (Usman, 2008).

Tujuan dalam penelitian ini adalah untuk mengetahui upaya kepala madrasah dalam meningkatkan kompetensi profesional guru dan mengetahui Faktor yang mendukung dan menghambat kepala madrasah dalam meningkatkan kompetensi profesional guru. Penelitian ini dilaksanakan di MI Almaarif 02 Singosari Malang. Lokasi ini dipilih karena lembaga ini merupakan salah satu Madrasah Ibtida'iyah yang berkembang pesat serta memiliki pengaruh yang besar di Kecamatan Singosari, Kabupaten Malang. Untuk batasan penelitian hanya pada permasalahan mengenai a) upaya kepala madrasah dalam meningkatkan kompetensi profesional guru b) Faktor yang mendukung dan menghambat kepala madrasah dalam meningkatkan kompetensi profesional guru di MI Almaarif 02 Singosari Malang.

\section{B. METODE PENELITIAN}

Jenis penelitian yang digunakan dalam penelitian ini adalah deskriptif. Penggunaan jenis penelitian deskripsi ini karena penelitian berangkat dari kerangka teori, gagasan para ahli, maupun dari pengalaman-pengalaman peneliti yang kemudian dikembangkan untuk memperoleh data empiris di lapangan. Penelitian ini berada MI Almaarif Singosari Malang. Dalam penelitian ini peneliti terlibat secara langsung dalam penelitian sebagai partisipan penuh mulai dari perencana, pelaksana dan pengumpulan data, menganalisis data, menafsirkan data, dan sebagai pelapor hasil penelitian. Peneliti 
menggunakan teknik pengumpulan data melalui observasi, wawancara, dan dokumentasi. Selanjutnya, dari teknik pengumpulan data akan di dapatkan sebuah data yang kemudian akan dianalisis dan ditarik kesimpulan.

\section{HASIL DAN PEMBAHASAN}

\section{Paparan Objek Penelitian}

MI Almaarif 02 Singosari Malang Yayasan Pendidikan Almaarif Singosari Malang sebagai salah satu mitra pemerintah, sebenarnya sudah lahir sebelum Proklamasi Kemerdekaan Negara Republik Indonesia, yaitu pada tahun 1923 dengan nama Madrasah Misbachul Wathon. Perkembangan selanjutnya setelah kemerdekaan Indonesia, Madrasah Nahdlatoel Wathon berubah nama menjadi Madrasah Nahdlatul Oelama yang dikenal dengan Sekolah Rakyat Nahdlatoel Oelama (SRNO). Tahun 1959 SRNO berubah menjadi Madrasah Ibtidaiyah NU/Wajib Belajar (MINU/MWB), MINU I dan MINU II. Kemudian pada tahun 1983 karena adanya peraturan pemerintah, madrasah harus berafiliasi pada salah satu departemen (Depag atau Dikbud), maka melalui rapat pada tanggal 10 april 1983 YP Al Maarif mengambil kebijakan MIA I menjadi SD Islam Al Maarif 02 dan MIA II menjadi Madrasah Ibtidaiyah Al Maarif 02 Singosari Malang.

Seiring dengan perkembangan dan pesatnya kemajuan pendidikan, maka lembaga MI Almaarif 02 singosari ini selalu berusaha untuk berbenah diri salah satunya dengan mengadakan penambahan guru dan peningkatan kompetensi guru. MI Almaarif 02 Singosari memiliki 27 tenaga pendidik. Sesuai dengan tuntutan kompetensi dan profesionalisme guru, para guru yang ada di madrasah ibtidaiyah almaarif ini sebagian besar mereka menempuh pendidikan sarjana strata satu (S1).

\section{Upaya Kepala Madrasah dalam Meningkatkan Kompetensi Profesional Guru di MI Almaarif 02 Singosari Malang}

Sekolah/Madrasah merupakan lembaga yang bersifat kompleks dan unik. Bersifat kompleks karena madrasah sebagai organisasi didalamnya terdapat berbagai dimensi yang satu dengan yang lain saling berkaitan dan saling menentukan. Sedangkan bersifat unik karena sekolah memiliki karakter tersendiri, dimana terjadi proses belajar mengajar, tempat terselenggaranya pembudayaan kehidupan manusia. Karena sifatnya yang kompleks dan unik tersebut sekolah sebagai organisasi memerlukan tingkat koordinasi yang tinggi. Maka dari itu kemajuan suatu madrasah ditentukan oleh kepala madrasah.

Kegiatan utama pendidikan di madrasah dalam mewujudkan tujuannya adalah kegiatan pembelajaran, sehingga seluruh aktivitas Organisasi pendidikan bermuara pada pencapaian efisiensi dan efektivitas pembelajaran. Oleh karena itu salah satu tugas kepala madrasah sebagai pemimpin harus memberikan layanan dan bantuan kepada guru agar guru menjadi guru yang ungul dan berkualitas. Siswa dapat menjadi unggul dan berkualitas berkat guru yang unggul dan berkualitas. Guru yang bekualitas dan unggul tidak terlepas dari dukungan kepala madrasah.

Guru memiliki empat kompetensi dasar guru diantaranya kompetensi pedagogik, kepribadian, sosial, dan profesional. Upaya kepala madrasah dapat dikatakan berhasil dan mengalami peningkatan apabila seorang guru mampu menguasai dan memahami kompetensi tersebut. Kepala madrasah harus memilki strategi yang tepat dalam memberikan peningkatan terhadap kompetensi keprofesionalan guru. 
Model peningkatan kompetensi tenaga pendidik yang dilaksanakan kepala madrasah MI Al-Maarif 02 Singosari terhadap guru terdiri dari dua macam model yaitu upaya yang dilakukan oleh kepala madrasah dalam bentuk formal maupun non formal. Adapun pembahasan dari upaya formal yang dilakukan adalah sebagai berikut:

a) Rapat Rutin

Rapat rutinan setiap satu bulan dengan menghadirkan seluruh guru madrasah. Dalam rapat rutin ini kepala madrasah mengagendakan beberapa kegiatan salah satunya terkait dengan eveluasi kinerja guru selama satu bulan terkait kegiatan belajar mengajar. Selain itu rapat rutinan ini bertujuan memusyawarahkan hal-hal yang terkait dengan berbagai permasalahan yang ada di madrasah tersebut. Upaya kepala madrasah tersebut sesuai dengan teori teknik supervisi kepala madarasah. (Karwati dan Priasa, 2013)

b) Diikutkan pelatihan, diklat dan seminar guru

Agar kemampuan guru semakin meningkat kepala madrasah MI Al-Maarif 02 Singosari mengikut serta kan guru-guru dalam pelatihan-pelatihan, misalnya; mengikutkan guru dalam wrokshop, pelatihan perangkatkan pembelajaran, kurikulum dan kegiatan yang terkait dengan kompetensi guru. Mengacu pada temuan diatas bahwa training atau pelatihan adalah suatu kegiatan yang dilakukan oleh guru agar guru-guru dapat merubah perilaku mereka dan kegiatan belajar mengajar dikelas. Pelatihan ini merupakan model pengembangan yang banyak di lakukan oleh lembaga pendidikan untuk pengembangan kemampuan profesional guru baik dalam rangka penyegaran maupun peningkatkan kemampuan.

c) Studi Kelompok antar Guru / KKG

Selain mengadakan workshop kepala madrasah juga melakukan peningkatan terhadap guru yaitu dengan mengikut sertakan guru dalam kelompok kerja guru (KKG).

d) Supervisi dan kunjungan kelas

Supervisi dan kunjungan kelas, yakni kunjungan yang dilakukan kepala madrasah ke dalam kelas pada saat guru sedang mengajar dengan tujuan untuk membantu guru yang bersangkutan menghadapi masalah/kesulitan selama mengadakan kegiatan pembelajaran. Kegiatan melakukan kunjungan kelas ini juga di lakukan oleh kepala madrasah MI Almaarif Singosari

e) Mengadakan Penilaian

Penilaian merupakan salah satu cara upaya yang dilakukan oleh Kepala madrasah. Penilaian ini bertujuan untuk menganalisis kompetensi guru dengan tujuan untuk meningkatkan kualitas profesional guru. Mengingat bahwa menjadi seorang guru harus menguasai kompetensi guru. Guru dapat dikatakan sukses apabila sudah menguasai dan mempraktikkan kompetensi tersebut. Maka dari itu kepala madrasah melakukan peningkatan dengan mangadakan penilaian terhadap guru yang berpacu pada kompetensi guru.

Sedangkan pembahasan upaya nonformal yang dilakukan oleh kepala madrasah dalam bentuk non formal adalah sebagai berikut:

a) Kedisiplinan

Dengan adanya disiplin waktu diharapkan bisa meningkatkan kompetensi profesional guru, terutama dalam menghargai waktu, sebab waktu sangat penting bagi guru sendiri maupun peserta didik. 
b) Memotivasi guru

Motivasi merupakan proses yang mendorong orang untuk melakukan sesuatu. Rutinitas pekerjaan sering menimbulkan kejenuhan yang mendalam yang dapat menurunkan motivasi guru untuk menjadi guru yang berkompetensi profesionalisme.

\section{Faktor Pendukung dan Penghambat Kepala Madrasah dalam Meningkatkan Kompetensi Profesional guru MI Al-Maarif 02 Singosari}

Dari hasil penelitian mengenai upaya kepala madrasah dalam meningkatkan kompetensi profesional guru, terdapat faktor pendukung dan penghambat yang dihadapi kepala madrasah, yakni sebagai berikut:

a) Faktor Pendukung

Faktor pendukung kepala madrasah dalam meningkatkan kompetansi guru MI Al-Maarif, yakni kemapuan kepala madrasah sendiri dalam meningkatkan kompetensi para guru. Terutama dalam tugasnya sebagai seorang pemimpin. Salah satu faktor pendukung yang terus menerus untuk meningkatkan kompetensi guru yaitu kelengkapan sarana prasarana.

b) Faktor Penghambat

Kompetensi profesional guru yang dilakukan kepala madrasah Al-Maarif 02 dalam meningkatkan kompetensi guru tidak selalu berjalan lurus, namun adakalanya mendapatkan suatu hambatan. Berikut hambatan-hambatan disampaikan kepala madrasah bahwa, segala sesuatu yang ingin dicapai itu pasti ada penghambat dan pendukungnya. Sama hal-nya dengan kepala madrasah yang mendapatkan dukungan ketika meningkatkan guru dan ada kalanya mengalami suatu hambatan dalam membina guru, terutama dalam meningkatkan kompetensi profesional guru.

\section{KESIMPULAN}

Bentuk upaya yang dilakukan oleh kepala madrasah dalam meningkatkan Kompetensi guru MI Almaarif 02 Singosari, khususnya dalam peningkatan Kompetensi tenaga pendidikan, kepala madrasah sudah memberikan upaya terhadap Kompetensi guru. Bentuk upaya yang diberikan oleh kepala madrasah yaitu berupa Kompetensi yang dilakukan baik formal dan non formal. Adapun upaya yang dilakukan kepala madrasah formal yaitu dengan Rapat Rutinan, mengikutkan pelatihan, diklat dan seminar guru, studi kelompok antar Guru / KKG, supervisi dan kunjungan kelas dan Mengadakan Penilaian.

Adapun kegiatan yang dilakukan non formal yaitu dengan membiasakan kedisiplinan dan selalu memberikan motivasi dengan tujuan untuk menambah wawasan guru, memberikan kesempatan kepada guru-guru untuk meningkatkan semangat disiplin dan keterampilan guru. Faktor pendukung dan penghambat Kepala Madrasah dari hasil penelitian telah diperoleh lima faktor pendukung dan penghambat, diantaranya tiga faktor pendukung yaitu; 1) sarana prasarana yang terpenuhi, 2) antusias para guru, 3) adanya dukungan dari yayasan. Adapun faktor penghambat terdiri dari dua faktor yaitu; 1) dari diri Kepala Madrasah dan 2) ketidaktepatan masuk madrasah.

\section{REFERENSI}

Asmani, Jamal Ma'mur. (2009). 7 Tip Cerdas E Efektif Lulus Sertifikasi Guru. Jogjakarta: Diva Press. 
Karwati, E. dan Priansa, J. Donni. (2013). Kinerja dan Profesionalisme Kepala Sekolah. Bandung: Alfabeta.

Kusmintaro dan Burhanuddin. (1997). Kepemimpinan Pendidikan Bagi Kepala Sekolah. Jakarta: Depdikbud.

Kunandar. (2008). Guru Profesional Implementasi Kurikulum Tingkat Satuan Pendidikan (KTSP) dan Sukses dalam Sertifikasi Guru. Jakarta: PT. Raja Grafindo Persada.

M. Daryanto. (2010). Administrasi pendidikan. Jakarta: Rineka Cipta.

Naim, Ngainun. (2011). Menjadi Guru Inspiratif. Yogyakarta: Pustaka Pelajar.

Oemar Hamalik. (2010). Pendidikan Guru Berdasarkan Pendekatan Kompetensi. Jakarta: PT Bumi Aksara

Soebagio Atmadiwiryo. (2000). Manajemen Pendidikan Indonesia. Jakarta: PT Ardadizya.

Udin Syaefudin Sau'ud. (2009). Pengembangan Profesi Guru. Bandung: CV. Alfabeta.

Usman, Moh. Uzer. (2008). Menjadi Guru Profesional. Bandung: PT. Remaja Rosda Karya. 